\title{
AKSELERASI:
}

JURNAL PENDIDIKAN GURU MI

Volume 2, Nomor 2, Juni 2021, Hal. 22-36

\section{PERSEPSI MAHASISWA FTIK IAIN JEMBER DALAM MEMAHAMI KOMPETENSI GURU YANG BERKUALITAS}

\author{
Widya Mellinda ${ }^{1}$, Fatimatus Zahroh ${ }^{2}$ \\ ${ }^{1}$ IAIN Jember, Jl. Mataram No.1 Mangli Jember, Jawa Timur Indonesia \\ e-mail:wiwid1205@gmail.com \\ fazahra358@gmail.com
}

DOI : 10.35719/akselerasi.v2i1.77

\begin{abstract}
The purpose of this study is to determine the perceptions of IAIN Jember students in understanding the competence of quality teachers. This research is a descriptive study which is carried out online or online by distributing questionnaires. The population of this study were students of the Faculty of Tarbiyah and Teacher Training at IAIN Jember with a sample of 100 students. The indicator used in this research is the Likert scale. Filled the questionnaire with an average score of 48\%, the indicator of knowledge about the competence of the perception teacher with an average panicle of 58,3\%, of indicators of understanding of the competence of the teacher's perceptions of student with an average of 39,6\%, understand the competence of teachers with an average score of 70,8\%. To create students as qualified prospective teachers, students are required to become professional teachers. And prpfessinal educators must have competent abilities that havebeen standardized and be able to demonstrate their quality as professional teachers.
\end{abstract}

Keywords: Perception, Student, Teacher Competence

\begin{abstract}
ABSTRAK
Tujuan dari penelitian ini adalah untuk mengetahui persepsi mahasiswa IAIN Jember dalam memahami kompetensi guru yang berkualitas. Penelitian ini adalah penelitian deskriptif yang dimana dilaksanakan secara daring atau online dengan menyebarkan kuisioner. Populasi penelitian ini adalah mahasiswa Fakultas Tarbiyah dan Ilmu Keguruan IAIN Jember dengan sampel sebanyak 100 mahasiswa. Indikator yang digunakan dalam penelitian ini adalah skala likert. Hasil penelitian menunjukkan bahwa kurangnya respon dari mahasiswa untuk mengisi kuisioner dengan nilai ratarata $48 \%$, indikator pengetahuan tentang kompetensi guru persepsi dengan nilai ratarata 58,3\%, indikator pemahaman tentang kompetensi guru persepsi mahasiswa dengan nilai rata-rata 39,6\%, dan indikator persepsi Mahasiswa sebagai calon guru tentang perlunya memahami kompetensi guru dengan nilai rata-rata 70,8\%. Untuk menciptakan mahasiswa sebagai calon guru yang berkualitas diperlukan kesiapan mahasiswa untuk menjadi guru profesional. Dan pendidik profesional harus memiliki kemampuan kompetensi yang telah distandarkan dan mampu menunjukkan kualitasnya sebagai guru yang profesional.
\end{abstract}

KataKunci: Persepsi, Mahasiswa, Kompetensi Guru 


\section{PЕМАНШ UA}

Keberadaan seorang guru merupakan salah satu faktor keberhasilan dalam menjamin kualitas dalam pedidikan. Mahasiswa calon guru harus memiliki standar kompetensi yang telah ditentukan, untuk menjadi seorang guru diperlukan keahlian khusus agar dapat melaksanakan tugasnya dengan baik. Oleh karena itu, negara menempatkan guru sebagai seorang profesional layaknya dokter, akuntan, dan profesi lainnya.

Tujuan pendidikan nasional adalah mencerdaskan kehidupan bangsa dan mengembangkan manusia Indonesia seutuhnya, yaitu manusia yang beriman dan bertaqwa terhadap Tuhan YME serta berbudi pekerti luhur, memiliki pengetahuan dan keterampilan, kesehatan jasmani dan rohani, kepribadian yang mantap dan mandiri serta rasa tanggung jawab kemasyarakatan dan kebangsaan. Dalam rangka mencapai tujuan pendidikan nasional dibutuhkan pendidik yang profesional. Sesuai dengan undang-undang Republik Indonesia No. 20 tahun 2003 tentang sistem pendidikan nasional, jabatan guru sebagai pendidik merupakan jabatan profesional. Oleh karena itu, Pendidikan adalah suatu kegiatan sosial yang memiliki peranan penting dalam kehidupan manusia yang berguna untuk memberikan pengetahuan, keterampilan kepada peserta didik, serta perubahan tingkah laku dan perilaku peserta didik.

Guru dituntut agar terus berkembang sesuai dengan perkembangan zaman, ilmu pengetahuan dan teknologi serta kebutuhan masyarakat akan sumber daya manusia yang berkualitas dan memiliki daya saing yang dapat dihandalkan. Sebagai calon seorang guru atau pendidik profesional harus memiliki kemampuan kompetensi yang telah distandarkan dan mampu menunjukkan kualitasnya sebagai guru yang profesional, karena itu kompetensi guru adalah sebuah penguasaan kemampuan kerja setiap guru atau pendidik yang mencakup aspek pengetahuan, keterampilan dan sikap kerja yang sesuai dengan standar yang ditetapkan.

Standar kompetensi guru yang harus dimiliki berdasarkan Permendiknas (Peraturan Menteri Pendidikan Nasional No. 16 tahun 2007, 2007) tentang standar kualifikasi akademik dan kompetensi guru menjelaskan bahwa standar kompetensi guru ini dikembangkan secara utuh dari empat kompetensi utama, yaitu kompetensi pedagogik, kepribadian, sosial, dan profesional. Keempat kompetensi tersebut terintegrasi dalam profesional guru. Keberhasilan secara profesional yang ditunjukkan guru secara umum menjadi tolak ukur mutu pendidikan yang baik.

Menurut (Sukmawati, Rika., 2019: 96), Standar kompetensi guru bertujuan untuk mendapatkan jaminan kualitas guru dalam meningkatkan kualitas proses pembelajaran. Dengan adanya standar kompetensi guru, maka tujuan pembelajaran dapat mudah diterapkan dan sesuai dengan yang diharapkan. Keempat standar kompetensi tersebut wajib dimiliki oleh seorang guru yang diperoleh melalui pendidikan profesi. 
Untuk menciptakan mahasiswa calon guru yang berkualitas diperlukan kesiapan mahasiswa untuk menjadi guru profesional. Hal ini sangat penting karena dengan memiliki kesiapan dapat meminimalisir kesalahan yang terjadi saat menjalani profesinya. Kesiapan calon guru sangat menentukan kualitas guru nantinya, semakin berkualitas gurunya maka akan semakin berkualitas mutu pendidikan. Kesiapan mahasiswa menjadi calon guru profesional merupakan keadaan yang menunjukkan bahwa mahasiswa sudah memenuhi persyaratan yang diwajibkan untuk menjadi guru yang profesional. Calon guru profesional dibutuhkan kesiapan dan banyak faktor yang mempengaruhi kesiapan tersebut. Faktor-faktor yang mempengaruhi kesiapan seorang calon guru dapat dikelompokkan menjadi 2 (dua) yaitu : 1) faktor internal yang meliputi minat menjadi guru; motivasi; kapasitas intelektual; pengetahuan; dan keterampilan. 2) faktor eksternal yang meliputi informasi tentang dunia kerja; pengaruh dari berbagai lingkungan (Keluarga, sekolah, dan teman sebaya); pengalaman-pengalaman yang didapatkan dari berbagai kegiatan yang menunjang terbentuknya kesiapan untuk menjadi seorang guru seperti Praktik Pengalaman Lapangan (PPL) (Sukmawati, 2019: 98).

Kesiapan menjadi guru dengan kemampuan maksimal perlu dimiliki untuk melaksanakan tugas utamanya sebagai seorang guru profesional. Kesiapan yang perlu dilakukan seorang guru berupa kemampuan penguasaan materi pelajaran, kemampuan fisik dan mental. Oleh karena itu calon guru sebaiknya sejak sedini mungkin perlu dipersiapkan secara matang agar siap menjadi guru dan menjalankan profesinya dengan optimal dan penuh tanggungjawab. Persiapan itu dimulai semenjak seorang calon guru mengikuti masa perkuliahan diperguruan tinggi (Sukmawati, 2019: 98).

Selain dari mahasiswa calon guru harus memiliki kesiapan dalam memahami kompetensi guru yang berkualitas. Jika dilihat dari visi FTIK IAIN Jember yaitu "Menjadi Pencetak Pendidik dan Tenaga Kependidikan yang Unggul, Berintegrasi, Profesional, dan Kompetitif Berbasis NilaiNilai Islam Nusantara". Hal ini memberikan kesempatan yang luas untuk menghasilkan selain sarjana pendidikan calon guru, juga menghasilkan sarjana-sarjana lain di luar ilmu pendidikan. Dengan menghasilkan tenaga kependidikan yang bermutu tinggi untuk memenuhi sistem pendidikan nasional dan mengembangkan ilmu pengetahuan, serta menghasilkan tenaga non kependidikan yang relevan.

Kualifikasi dan kompetensi merupakan syarat penting yang harus dimiliki oleh guru. Kualifikasi akademik merujuk pada syarat formal formal yang harus diselesaikan melalui aktivitas akademik tertentu dan dapat dibuktikan melalui dengan ijazah atau sertifikat yang dimiliki setelah menyelesaikan masa studi pada jenjang pendidikan, dalam hal ini jenjang pendidikan S1/ D-IV seperti yang diisyaratkan UU No. 14 tahun 2005 (Payong, 2011: 17).

Latar belakang diatas, maka perlu dilakukan penelitian untuk melihat sejauh mana mahasiswa sebagai calon guru harus memahami kompetensi guru, dengan begitu dapat menjadi 
guru yang berkualitas atau profesional. Munculnya berbagai persepsi dalam memahami kompetensi guru yang terfokus pada mahasiswa merupakan suatu pandangan atau proses penerimaan, pengorganisasian, penginterpretasian mahasiswa dalam memahami kompetensi guru, dengan begitu mahasiswa sebagai calon guru seharusnya mempunyai minat dengan menguasai atau memahami empat kompetensi guru yaitu kompetensi pedagogik, kepribadian, sosial, dan profesional. Berdasarkan penjelasan diatas, maka penulis ingin mengetahui bagaimana persepsi mahasiswa IAIN Jember dalam memahami kompetensi guru yang berkualitas.

\section{TINJAUAN PUSTAKA}

\section{A. Persepsi}

Menurut (Soraya, 2018: 189) mengenai Persepsi adalah proses pemahaman ataupun pemberian makna atas suatu informasi terhadap stimulus. Stimulus didapat dari proses penginderaan terhadap objek, peristiwa, atau hubungan-hubungan antar gejala yang selanjutnya diproses oleh otak. Proses kognitif dimulai dari persepsi. External perception, yaitu persepsi yang terjadi karena adanya rangsangan yang datang dari luar diri individu, yaitu persepsi yang terjadi karena adanya rangsang yang berasal dari dalam individu. Dalam hal ini yang menjadi objek adalah dirinya sendiri. Oleh karena itu, persepsi adalah proses kognitif yang dimiliki setiap orang dalam memahami informasi tentang lingkunganya melalui panca indra, dan tiap-tiap individu dapat memberikan arti atau tanggapan yang berbeda-beda.

Adanya faktor- faktor yang mempengaruhi persepsi, pendapat Wilson (dalam Soraya, 2018: 189), mengemukakan ada faktor dari luar dan dari dalam yang mempengaruhi persepsi diantaranya sebagai berikut :

a. Faktor Eksternal atau dari luar: Concreteness yaitu wujud atau gagasan yang abstrak yang sulit dipersepsikan dibandingkan dengan yang objektif. Novelty atau hal yang baru, biasanya lebih menarik untuk dipersepsikan dibandingkan dengan hal-hal yang baru. Velocity atau percepatan misalnya gerak yang cepat untuk menstimululasi munculnya persepsi lebih efektif di bandingkan dengan yang lambat. Coditioned stimuli, stimuli yang dikondisikan seperti bel pintu, dering telepon dan lain-lain.

b. Faktor Internal atau dari dalam: Motivation, misalnya merasa lelah menstimulasi untuk merespon istirahat. Interest, hal-hal yang menarik lebih diperhatikan dari pda yang tidak menarik Need, kebtuhan akan hal itu tertentu akan menjadi pusat perhatian Assumptions, juga mempengaruhi persepsi sesui dengan pengalaman melihat, merasakan dan lain-lain.

Menurut Rahmat (dalam Soraya, 2018: 189) yaitu terdapat faktor-faktor yang personal yang mempengaruhi persepsi interpersonal adalah: 
a. Pengalaman seseorang yang telah mempunyai pengalaman tentang hak-hak tertentu akan mempengaruhi kecermatan seseorang dalam memperbaiki persepsi.

b. Motivasi, motivasi yang sering mempengaruhi persepsi interpersonal adalah kebutuhan untuk mempercayai "dunia yang adil" artinya kita memercayai dunia ini telah diatur secara adil.

c. Kepribadian dalam psikoanalisis dikenal sebagai proyeksi yaitu usaha untuk mengekternalisasikan pengalaman subyektif secara tidak sadar, orang mengeluarkan perasaan beraalnya dari orang lain.

Dari penjelasan diatas, persepsi seseorang tidak timbul dengan sendirinya, akan tetapi melalui proses dan faktor-faktor yang mempengaruhi persepsi seseorang. Hal inilah yang menyebabkan setiap orang memiliki pandangan yang berbeda-berbeda, walaupun apa yang dilihat sama. Proses pembentukan persepsi dapat dipengaruhi oleh berbagai hal yaitu dengan adanya pengalaman, kemampuan, individu, lingkungan dan lainya, proses pembentukan itu sendiri dapat dikelompokan menjadi faktor internal dan eksternal.

\section{B. Kompetensi Guru}

Kompetensi merupakan kemampuan yang digunakan sebagai standar kinerja seseorang yang diharapkan dapat berkontribusi positif terhadap kinerja organisasi. Kompetensi memiliki arti yang luas dan variatif, dan dalam implementasinya disesuaikan dengan kebutuhan organisasi dan individu yang bersangkutan. Inti pokok dari definisi kompetesi adalah penjelasan mengenai tugas-tugas pekerjaan yang dilakukan oleh individu dan penjelasan mengenai perilaku individu yang berhubungan dengan bagaimana individu itu mengerjakan pekerjaanya.

Menurut (Fauzi, 2018: 144), kompetensi menunjuk pada kinerja seseorang dalam suatu pekerjaan yang bisa dilihat dari pikiran, sikap, dan perilaku. Karakteristik kompetensi yaitu sebagai berikut :

1. Motif, yaitu sesuatu yang orang fikirkan dan inginkan yang menyebabkan sesuatu.

2. Sifat, yaitu karakteristik fisik tanggapan konsisten terhadap situasi.

3. Konsep diri, yaitu sikap, nilai, dan image dari seseorang.

4. Pengetahuan, yaitu informasi yang dimiliki seseorang dalam bidang tertentu.

5. Keterampilan, yaitu kemampuan untuk melakukan tugastugas yang berkaitan dengan fisik dan mental.

Menurut Mulyasa (dalam Fauzi, 2018: 144-145), mengemukakan bahwa kompetensi dapat diartikan sebagai pengetahuan, keterampilan, dan kemampuan yang dikuasai oleh seseorang yang telah menjadi bagian dari dirinya, sehingga ia dapat melakukan perilaku-perilaku kognitif, afektif dan psikomotorik dengan sebaik-baiknya. Dalam UU No. 14 Tahun 2005 tentang Guru dan Dosen, juga disebutkan bahwa kompetensi adalah seperangkat pengetahuan, 
keterampilan, dan perilaku yang harus dimiliki, dihayati dan dikuasai oleh guru dan dosen dalam melaksanakan tugas keprofesionalannya.

Dalam hal ini, guru mempunyai peranan yaitu memiliki tugas mulia untuk mendorong, membimbing dan memberi fasilitas belajar bagi siswa untuk mencapai tujuan. Guru mempunyai tanggung jawab untuk melihat segala sesuatu yang terjadi dalam kelas untuk membantu proses perkembangan siswa. Penyampaian materi pelajaran sebagai salah satu dari berbagai kegiatan dalam belajar yang dimana suatu proses yang terus berkembang aktif dalam segala fase dan proses perkembangan siswa.

Menurut (Aquami,dkk., 2018) berpendapat kompetensi guru dapat dimaknai sebagai kebulatan pengetahuan, keterampilan dan sikap yang berwujud tindakan cerdas dan penuh tanggung jawab dalam melaksanakan tugas sebagai agen pembelajaran. Guru merupakan salah satu faktor yang sangat penting dalam meningkatkan kualitas pendidikan. Di tangan guru yang cekatan; fasilitas dan sarana yang kurang memadai dapat diatasi, tetapi sebaliknya ditangan guru yang kurang cakap: sarana dan fasilitas yang canggih tidak banyak memberi manfaat.

Berangkat dari masalah di atas, maka langkah pertama yang dilakukan untuk memperbaiki kualitas pendidikan adalah dengan memperbaiki kualitas tenaga pendidiknya terlebih dahulu. Oleh karena itu, salah satu langkah untuk menjadi guru profesional yang nantinya akan meningkatkan kualitas pendidikan adalah guru harus memiliki kompetensi.

Pengertian lain mengenai Kompetensi merupakan kemampuan dalam menguasai pengetahuan mengenai pendidikan dan memiliki berbagai macam keterampilan baik secara IPTEK maupun non IPTEK, serta harus memiliki perilaku yang luhur karena guru merupakan panutan bagi peserta didik. Kompetensi itu sendiri terdiri dari empat kompetensi yaitu: kompetensi pedagogik, kompetensi kepribadian, kompetensi profesional, dan kompetensi sosial (Fauzi, 2018: 145).

Dari pengertian di atas dapat disimpulkan bahwa kompetensi yang harus dimiliki guru ataupun calon guru adalah kemampuan-kemampuan yang berupa seperangkat pengetahuan, keterampilan, dan perilaku yang harus dimiliki, dihayati, dan dikuasai oleh guru agar dapat menjalankan tugas keprofesionalannya. Standar kompetensi guru terdiri dari empat kompetensi yaitu: kompetensi pedagogik, kompetensi kepribadian, kompetensi profesional, dan kompetensi sosial.

\section{Kompetensi Pedagogik}

Dalam (Fauzi, 2018: 145-146), mengenai PP No. 19 tahun 2005 jo PP No. 32 tahun 2013 tentang Standar Nasional Pendidikan, pasal 28 (3) dibutir a dikemukakan bahwa kompetensi pedagogik adalah kemampuan mengelola pembelajaran peserta didik yang meliputi pemahaman terhadap peserta didik, perancangan dan pelaksanaan pembelajaran, 
evaluasi hasil belajar, dan pengembangan peserta didik untuk mengaktualisasikan berbagai potensi yang dimilikinya.

Menurut (Sukmawati, 2019: 96-97) mengenai kompetensi pedagogik merupakan kompetensi dalam mengelola dan memahami peserta didik dengan menguasai teori-teori tentang pendidikan guna mengembangkan peserta didik untuk mampu mengaktulisasikan berbagai potensi yang dimiliki peserta didiknya. Kompetensi pedagogik juga merupakan kemampuan menyusun dan mengembangkan rencana pelaksanaan pembelajaran dengan menguasai teknik-teknik dan metode pembelajaran berdasarkan landasan kurikulum pendidikan, mampu melaksanakan pembelajaran yang mendidik dan dialogis dengan memanfaatkan teknologi pembelajaran dan mampu membuat evaluasi proses dari hasil pembelajaran.

Dalam (Fauzi, 2018: 146) yaitu PP No. 74 tahun 2008 tentang Guru, pasal 3 ayat (4) juga dijelaskan, kompetensi pedagogik sebagaimana merupakan kemampuan guru dalam pengelolaan pembelajaran peserta didik yang sekurang-kurangnya meliputi:

a. Pemahaman wawasan atau landasan kependidikan;

b. Pemahaman terhadap peserta didik;

c. Pengembangan kurikulum atau silabus;

d. Perancangan pembelajaran;

e. Pelaksanaan pembelajaran yang mendidik dan dialogis;

f. Pemanfaatan teknologi pembelajaran;

g. Evaluasi hasil belajar; dan

h. Pengembangan peserta didik untuk mengaktualisasikan berbagai potensi yang dimilikinya.

Dalam pedagogik, guru dianggap sebagai pihak yang paling bertanggung jawab untuk mengarahkan pembelajaran, apa yang akan dipelajari, bagaimana mempelajarinya dan kapan suatu materi dipelajari. Dengan demikian, kehadiran guru menjadi fokus kegiatan pendidikan kesetaraan. Namun faktanya menunjukkan bahwa belajar tidak hanya melalui guru, tetapi dapat melalui refleksi diri, pengalaman hidup, pengendapan pengalaman dan melalui berbagai macam aktivitas. Dari pandangan ini mengisyaratkan bahwa pedagogik bukanlah pendekatan belajar yang sesuai (relevan) bagi orang dewasa. Hal itu, berbeda dengan andragogik. Andragogik menempatkan orang dewasa dalam layanan pendidikan yang bersifat demokratis, bertumpu kepada kesejajaran, kesepadanan dan persamaan perilaku kegiatan belajar. Dengan demikian, andragogik adalah proses pembelajaran yang dapat membantu orang dewasa menemukan dan menggunakan hasil temuannya yang berkaitan dengan lingkungan sosial, adanya interaksi dan saling pengaruh antara tutor dengan peserta didik (Fauzi, 2018: 147). 
Dari penjelasan diatas, dapat disimpulkan bahwa kompetensi pedagogik yang dimana kemapuan penguasaan teori-teori pembelajaran yang terfokus untuk peserta didik atau anak-anak agar mampu mengaktulisasikan berbagai potensi yang dimiliki. Sedangkan kompetensi andragogik yang dimana teori-teori pembelajaran kepada perkembangan kebutuhan orang dewasa yang adanya keterkaitan dengan lingkungan sosial dan interaksi serta tutor dengan peserta didik.

\section{Kompetensi Kepribadian atau Personal}

Dalam (Fauzi, 2018: 149) yaitu PP No. 19 tahun 2005 jo PP No. 32 tahun 2013, pasal 28 (3) butir b, dikemukakan bahwa yang dimaksud dengan kompetensi kepribadian adalah kemampuan kepribadian yang mantap, stabil, dewasa, arif dan berwibawa, menjadi teladan bagi peserta didik, dan berakhlak mulia.

Menurut (Sukmawati, 2019: 97) mengenai kompetensi kepribadian merupakan kemampuan individu atau personal yang mencerminkan kepribadian yang dewasa, bijaksana, arif, objektif, berwibawa, stabil, konsisten, displin, jujur, berwawasan luas, bertanggung jawab, berakhlak mulia dan mampu menjadi teladan bagi peserta didiknya karena guru merupakan role model yang di tiru dan di gugu sebagai sumber inspirasi positif bagi peserta didiknya. Selain itu kemampuan mengevaluasi diri sendiri secara objektif dan mengembangkan diri secara mandiri dan berkelanjutan.

Menurut (Fauzi, 2018: 150) berpendapat bahwa sebagai pribadi guru merupakan perwujudan diri dengan seluruh keunikan karakteristik yang sesuai dengan posisinya sebagai pemangku profesi keguruan. Kepribadian merupakan landasan utama bagi perwujudan diri sebagai guru yang efektif baik dalam melaksanakan tugas profesionalnya di lingkungan pendidikan dan di lingkungan kehidupan lainnya. Hal ini mengandung makna bahwa seorang guru harus mampu mewujudkan pribadi yang efektif untuk dapat melaksanakan fungsi dan tanggung jawabnya sebagai guru. Untuk itu, ia harus mengenal dirinya sendiri dan mampu mengembangkannya ke arah terwujudnya pribadi yang sehat dan paripurna (fully functioning person).

Dalam (Fauzi, 2018: 150-151) mengenai PP No. 74 tahun 2008, pasal 3 ayat (5) dijelaskan, kompetensi kepribadian sekurang-kurangnya mencakup kepribadian yang beriman dan bertakwa, berakhlak mulia, arif dan bijaksana, demokratis, mantap, berwibawa, stabil, dewasa, jujur, sportif, menjadi teladan bagi peserta didik dan masyarakat, secara obyektif mengevaluasi kinerja sendiri, dan mengembangkan diri secara mandiri dan berkelanjutan.

Oleh karena itu, dapat disimpulkan bahwa kompetensi kepribadian adalah kemampuan yang harus dimiliki seorang individu yang dimana memiliki kepribadian yang dewasa, bijaksana, arif, objektif, berwibawa, stabil, konsisten, displin, jujur, berwawasan luas, 
bertanggung jawab, berakhlak mulia dan mampu menjadi teladan bagi peserta didiknya. Serta dengan adanya kompetensi kepribadian menjadi landasan dalam mewujudkan pribadi sebagai guru yang efektif untuk dapat melaksanakan fungsi dan tanggung jawabnya sebagai guru.

\section{Kepribadian Profesional}

Dalam (Fauzi, 2018: 151) mengenai PP No. 19 tahun 2005 jo PP No. 32 tahun 2013 pasal 28 (3) butir c, dikemukakan bahwa yang dimaksud dengan kompetensi profesional adalah kemampuan penguasaan materi pembelajaran secara luas dan mendalam yang memungkinkan membimbing peserta didik memenuhi standar kompetensi yang ditetapkan standar nasional pendidikan.

Menurut (Fauzi, 2018: 151-152) berpendapat bahwa kompetensi profesional merupakan kemampuan guru dalam penguasaan materi pelajaran secara luas dan mendalam. Proses belajar dan hasil belajar peserta didik bukan saja ditentukan oleh sekolah, pola, struktur, dan isi kurikulumnya, akan tetapi sebagian besar ditentukan oleh kompetensi guru yang mengajar mereka. Guru yang kompeten akan lebih mampu menciptakan lingkungan belajar yang efektif, menyenangkan, dan akan lebih mampu mengelola kelasnya, sehingga belajar peserta didik berada pada tingkat optimal.

Dalam (Fauzi, 2018: 151-152) mengenai PP No. 74 tahun 2008, pasal 3 ayat (7) dijelaskan, kompetensi profesional merupakan kemampuan guru dalam menguasai pengetahuan bidang ilmu pengetahuan, teknologi, dan/atau seni dan budaya yang diampunya yang sekurang-kurangnya meliputi penguasaan:

a. Materi pelajaran secara luas dan mendalam sesuai dengan standar isi program satuan pendidikan, mata pelajaran, dan/atau kelompok mata pelajaran yang akan diampu;

b. Konsep dan metode disiplin keilmuan, teknologi, atau seni yang relevan, yang secara konseptual menaungi atau koheren dengan program satuan pendidikan, mata pelajaran, dan/atau kelompok mata pelajaran yang akan diampu.

Dari penjelasan diatas, dapat disimpulkan bahwa kompetensi profesional merupakan kemampuan guru dalam penguasaan yang secara luas dan mendalam mengenai materi pembelajaran dengan pengetahuan bidang ilmu pengetahuan, teknologi, dan/atau seni dan budaya sehingga wawasan yang luas terhadap materi tersebut dan materi yang relevan.

\section{Kompetensi Sosial}

Dalam (Fauzi, 2018: 152) mengenai PP No. 19 tahun 2005 jo PP No. 32 tahun 2013 pasal 28 (3) butir d, dikemukakan bahwa yang dimaksud kompetensi sosial adalah kemampuan guru dari sebagian masyarakat untuk berkomunikasi dan bergaul secara efektif dengan peserta didik, sesama pendidik, tenaga kependidikan, orang tua/wali peserta didik, dan masyarakat sekitar. 
Menurut (Fauzi, 2018: 153) berpendapat bahwa inti dari kompetensi sosial terletak pada komunikasi, tetapi komunikasi yang dimaksud adalah komunikasi yang efektif. Komunikasi dapat diartikan sebagai suatu proses saling mempengaruhi antar manusia. Komunikasi juga merupakan keseluruhan dari pada perasaan, sikap, dan harapan-harapan yang disampaikan baik secara langsung atau tidak langsung, baik yang dilakukan secara sadar atau tidak sadar karena komunikasi merupakan bagian integral dari proses perubahan.

Menurut (Sukmawati, 2019:97) juga berpendapat bahwa kompetensi sosial merupakan kemampuan dalam melakukan komunikasi baik secara lisan, tulisan, maupun perilaku yang mampu bekerjasama dan beradaptasi dengan peserta didik, teman sejawat, orang tua peserta didik, tenaga kependidikan, pimpinan satuan pendidikan dan masyarakat yang beranekaragam suku, budaya dan kebiasaan yang berada di sekitar tempat melaksanakan tugas. Kemampuan komunikasi tersebut dilakukan secara efektif, ramah, santun, beradab dan berdasarkan norma yang berlaku serta mampu menggunakan teknologi komunikasi dan informasi secara fungsional dengan menerapkan prinsip-prinsip persaudaraan sejati dan semangat kebersamaan.

Dalam (Fauzi, 2018: 153-154) mengenai PP No. 74 tahun 2008, pasal 3 ayat (6) dijelaskan, kompetensi sosial merupakan kemampuan guru sebagai bagian dari masyarakat yang sekurang-kurangnya meliputi kompetensi untuk:

a. Berkomunikasi lisan, tulis, dan/atau isyarat secara santun;

b. Menggunakan teknologi komunikasi dan informasi secara fungsional;

c. Bergaul secara efektif dengan peserta didik, sesama pendidik, tenaga kependidikan, pimpinan satuan pendidikan, orang tua peserta didik;

d. Bergaul secara santun dengan masyarakat sekitar dengan mengindahkan norma serta sistem nilai yang berlaku; dan

e. Menerapkan prinsip persaudaraan sejati dan semangat kebersamaan.

Oleh karena itu, dapat disimpulkan bahwa kompetensi sosial merupakan kemampuan guru untuk berkomunikasi efektif secara lisan, tulisan, maupun perilaku serta dapat bergaul secara efektif dengan peserta didik, sesama pendidik, tenaga kependidikan, orang tua atau wali peserta didik, dan masyarakat sekitar.

\section{METODE}

Penelitian ini adalah penelitian deskriptif yaitu penelitian yang bertujuan untuk mengetahui perkembangan sarana fisik tertentu atau frekuensi terjadinya sesuatu aspek fenomena sosial tertentu, dan untuk mendeskripsikan fenomena tertentu secara terperinci. Menurut Suryana (2010: 16) yaitu pada metode ini dimulai dengan mengumpulkan data, menganalisis data dan menginterprestasikannya. Metode deskriptif dalam pelaksanaannya dilakukan melalui: teknik 
survey, studi kasus (bedakan dengan suatu kasus), studi komparatif, studi tentang waktu dan gerak, analisis tingkah laku, dan analisis dokumenter. Pada penelitian ini hanya akan dipaparkan data yang diperoleh dari hasil analisis kuisioner persepsi mahasiswa untuk selanjutnya diinterpretasikan.

Penelitian ini dilaksanakan mahasiswa Fakultas Tarbiyah dan Ilmu Keguruan IAIN Jember pada bulan oktober tahun 2020. Populasi menurut Sugiyono (2018:130) merupakan wilayah generalisasi yang terdiri dari obyek/subjek yang mempunyai kualitas dan karakteristik tertentu yang ditetapkan oleh peneliti untuk dipelajari dan kemudian ditarik kesimpulannya. Sedangkan sampel adalah bagian dari jumlah dan karakteristik yang dimiliki oleh populasi. Populasi pada penelitian ini dengan sampel sebanyak 100 mahasiswa. Data yang dikumpulkan berupa data kualitatif yaitu deskripsi dari persepsi mahasiswa calon guru dalam memahami kompetensi guru yang berkualitas.

Teknik pengumpulan data dalam penelitian ini adalah kuisioner. Menurut Sugiyono (2017 : 199) kuisioner merupakan teknik pengumpulan data yang dilakukan dengan cara memberi seperangkat pertanyaan atau pernyataan tertulis yang dilakukan dengan cara memberi seperangkat pertanyaan atas penyataan tertulis kepada responden untuk dijawabnya. Instrument penelitian menggunakan angket atau kuisioner dengan 3 sampai 4 indikator, berisi 3 pertanyaan. Dari indikator untuk mengetahui setiap jawaban pertanyaan maka digunakan skala Likert. Menurut Sugiyono (2017: 134) skala likert digunakan untuk mengukur sikap, pendapat, dan persepsi seseorang atau sekelompok orang tentang fenomena sosial.untuk setiap pertanyaan atau pernyataan responden harus mendukung sebuah pertanyaan untuk dipilih. Dengan skala likert responden memilih jawaban dari variabel yang dipecah menjadi bagian dari indicator variabel, masing-masing indikator variabel mempunyai instrumen yang dijadikan tolak ukur dalam sebuah pertanyaan atau pernyataan. Skala dalam penelitian menggunakan katagori yang berbeda. Pengisian angket ini dengan memberi tanda checklist $(\sqrt{ }$ ) pada jawaban yang sesuai menurut responden. Teknik analisis data digunakan peneliti adalah analisis deskriptif.

Analisis data dilakukan dengan metode deskriptif yaitu dengan teknik persentase. Data ditabulasi dengan menyusun ke dalam tabel sistematis kemudian dihitung persentasenya untuk selanjutnya dianalisis dan diinterpretasikan. Data dari angket dalam penelitian ini merupakan data kuantitatif yang akan dianalisis secara deskriptif persentase dengan langkah-langkah sebagai berikut :

1. Menghitung nilai responden dan masing-masing aspek atau sub variabel.

2. Merekap nilai.

3. Menghitung nilai rata-rata.

4. Menghitung persentase dengan rumus:

$$
D P=\frac{n}{N} \times 100 \%
$$


Keterangan:

$\mathrm{DP}=$ Deskriptif Persentase $(\%)$

$\mathrm{n} \quad=\quad$ Skor empirik (Skor yang diperoleh)

$\mathrm{N}=$ Skor Ideal untuk setiap item pertanyaan

Untuk menentukan jenis deskriptif persentase yang diperoleh masing-masing indikator dalam variabel, dan perhitungan deskriptif persentase kemudian ditafsirkan kedalam kalimat. Selain itu, untuk mengetahui tingkat kriteria tersebut, selanjutnya skor yang diperoleh (dalam \%) dengan analisis deskriptif persentase dikonsultasikan dengan tabel kriteria.

Tabel 1. Kriteria Analisis Deskriptif Persentase

\begin{tabular}{|l|c|c|}
\hline No. & Persentase & Kriteria \\
\hline \hline 1. & $75 \%-100 \%$ & Sangat Baik \\
\hline 2. & $50 \%-75 \%$ & Baik \\
\hline 3. & $25 \%-50 \%$ & Cukup Baik \\
\hline 4. & $1 \%-25 \%$ & Kurang Baik \\
\hline
\end{tabular}

\section{HASIL DAN PEMBAHASAN}

Data yang didapat dalam penelitian ini tentang Persepsi Mahasiswa IAIN Jember dalam memahami kompetensi guru yang berkualitas, terdapat 48 respon atau tanggapan dari sampel 100 mahasiswa dari berbagai semester yang mengisi kuisioner atau angket sebagai berikut :

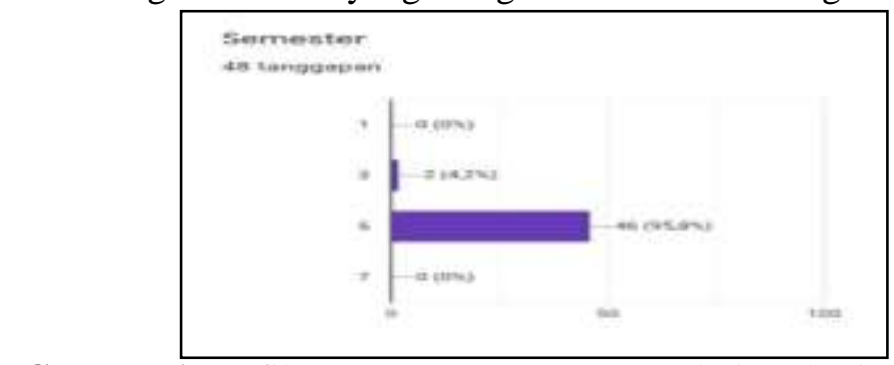

\section{Gambar 1.Grafik Respon atau Tanggapan dari Mahasiswa IAIN Jember berbagai Semester yang Mengisi Kuisioner.}

Dari data grafik di atas didapat penjelasan mengenai respon mahasiswa IAIN Jember yang mengisi kuisioner atau angket hanya sekitar 48 respon atau tanggapan dari 100 kuisioner yang disebarkan. Hal ini hanya sekitar $48 \%$ dari $100 \%$ yang menanggapi kuisioner ini, karena kurangnya respon dari mahasiswa karena kuisioner ini di laksanakan secara daring atau online.

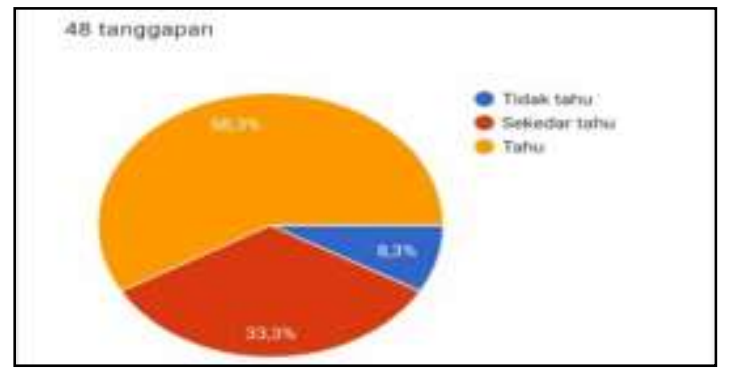




\section{Gambar 2.Grafik Persepsi Mahasiswa Sebagai Calon Guru}

Tentang Pengetahuan Kompetensi Guru

Dari data grafik diatas, dapat diketahui bahwa persepsi mahasiswa sebagai calon guru yang mengetahui kompetensi guru yaitu sekitar 58,3\%, itu tandanya lebih dari sampel mahasiswa yang mengetahui akan kompetensi guru. Sisanya terdapat 33,3\% persepsi mahasiswa yang sekedar tahu tentang kompetensi guru, dan $8,3 \%$ persepsi mahasiswa yang tidak tahu tentang kompetensi guru.

Oleh karena itu, seorang calon guru perlu mengetahui adanya kompetensi guru yang berkualitas agar sesuai dengan standar kompetensi guru yang harus dimiliki berdasarkan Permendiknas (Peraturan Menteri Pendidikan Nasional No. 16 tahun 2007, 2007) tentang standar kualifikasi akademik dan kompetensi guru menjelaskan bahwa standar kompetensi guru ini dikembangkan secara utuh dari empat kompetensi utama, yaitu kompetensi pedagogik, kepribadian, sosial, dan profesional. Karena keberhasilan secara profesional ditunjukkan guru secara umum dan dijadikan tolak ukur mutu pendidikan yang baik.

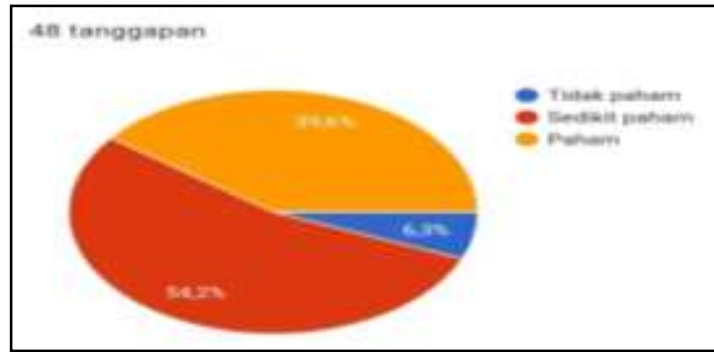

Gambar 3. Grafik Persepsi Mahasiswa Sebagai Calon Guru

Tentang Pemahaman Kompetensi Guru.

Dari data grafik diatas, bisa dilihat bahwasannya persepsi mahasiswa sebagai calon guru yang paham terhadap kompetensi guru yaitu sekitar 39,6\%, itu tandanya hampir sebagian dari sampel mahasiswa yang paham akan kompetensi guru. Sisanya terdapat 54,2 \% persepsi mahasiswa yang sedikit paham tentang kompetensi guru, dan 6,3\% persepsi mahasiswa yang tidak paham tentang kompetensi guru.

Oleh karena itu, diperlukannya pemahaman kepada mahasiswa sebagai calon guru agar memiliki kompetensi yang sesuai yaitu kompetensi guru. Karena dalam profesi guru dengan profesi lainnya terletak dalam tugas dan tanggung jawabnya. Maka diperlukannya kemampuan serta kepahaman yang berupa seperangkat pengetahuan, keterampilan, dan perilaku yang harus dimiliki, dihayati, dan dikuasai oleh guru maupun agar dapat menjalankan tugas keprofesionalannya. Selain itu, perlunya motivasi dari diri sendiri dan lingkungan agar bisa menjadi seorang guru yang memiliki kompetensi guru yang berkualitas. 


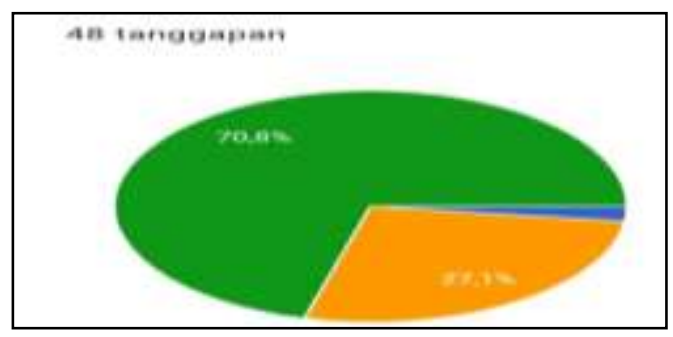

Gambar 4.Grafik Persepsi Mahasiswa Sebagai Calon Guru

Tentang Pentingnya Memahami Kompetensi Guru

Dari data grafik diatas, terlihat bahwasannya dari persepsi mahasiswa sebagai calon guru yang menganggap sangat pentingnya dalam memahami kompetensi guru adalah 70,8 \%. Selanjutnya dari data itu juga terdapat persepsi mahasiswa sebagai calon guru yang menganggap pentingnya memahami kompetensi guru sekitar $27,1 \%$. Sedangkan yang menganggap untuk tidak pentingnya memahami kompetensi guru sekitar 2,1\%.

Respon mahasiswa sebagai calon guru tersebut yang menganggap bahwa sangat pentingnya dalam memahami kompetensi guru yang berkualitas menandakan bahwasannya mereka sebagai calon guru sangat membutuhkan pengetahuan yang luas akan kompetensi yang harus dimiliki seorang guru dengan begitu akan menjadikan mereka sebagai guru yang berkompeten dan profesional dibidang yang dikuasai. Sedangkan pada mahasiswa yang menganggap tidak perlu maka sebaiknya di berikan pandangan atau pemahaman akan kompetensi guru yang berkualitas. Pelaksanaan tugas sebagai guru harus didukung oleh suatu perasaan bangga akan tugas yang dipercayakan kepadanya untuk mempersiapkan generasi kualitas masa depan bangsa

Berdasarkan uraian persepsi dari mahasiswa sebagai calon guru tersebut dapat disimpulkan bahwa kompetensi merupakan kemampuan dalam menguasai pengetahuan mengenai pendidikan dan harus memiliki berbagai macam keterampilan. Karena sejatinya menjadi seorang guru merupakan panutan bagi anak didik, baik itu guru formal maupun guru informal. Dan seorang guru harus memahami kompetensi yang arus dimiliki dari seorang guru. Kompetensi itu sendiri terdiri dari empat kompetensi yaitu: kompetensi pedagogik, kompetensi kepribadian, kompetensi pofesional, dan kompetensi sosial.

\section{KESIMPULAN}

Berdasarkan hasil penelitian yang telah diuraikan di atas, maka dapat ditarik kesimpulan sebagai berikut bahwa persepsi mahasiswa Fakultas Tarbiyah dan Ilmu Keguruan IAIN Jember sebagai calon guru dalam merespon tanggapan kuisioner dalam memahami kompetensi guru dengan nilai rata-rata 48\%, hal ini karena kurang adanya respon dari mahasiswa saat penyebaran kuisioner yang dilakukan secara online. Pada indikator pengetahuan tentang kompetensi guru, persepsi mahasiswa kurang lebih sudah baik dengan nilai rata-rata 58,3\%, karena sebagai calon guru harus mengetahui tentang kompetensi guru. Pada indikator pemahaman tentang kompetensi 
guru, persepsi mahasiswa kurang baik dengan nilai rata-rata 39,6\%, karena persepsi mahasiswa sebagai calon guru tidak membuat semua mahasiswa paham mengenai pemahaman tentang kompetensi guru. Pada indikator persepsi Mahasiswa sebagai calon guru tentang pentingnya memahami kompetensi guru dengan nilai rata-rata 70,8\%, karena salah satu syarat sebagai guru harus memiliki kompetensi (kemampuan) untuk melaksanakan kegiatan pengajaran dan pendidikan dengan optimal.

\section{DAFTAR PUSTAKA}

Aquami, dkk. 2018. Hubungan Kompetensi Guru dan Peran Orang Tua Terhadap Terhadap Hasil Belajar Siswa di MIN Se-Kota Palembang. Jurnal Ilmiah PGMI, Volume 4, No.1.

Fauzi, Imron. 2018. Etika Profesi Keguruan. Jember: IAIN Jember Press.

Payong, M. R. (2011). Sertifikasi Profesi Guru: Konsep Dasar, Problematika dan Implementasinya. Jakarta: Indeks.

Peraturan Menteri Pendidikan Nasional Nomor 16 tahun 2007 tentang Standar Kualifikasi Akademik dan Kompetensi Guru.

Soraya, Nyanyu. 2018. Analisis Persepsi Mahasiswa Terhadap Kompetensi Dosen Dalam Mengajar Pada Program Studi PAI Fakultas Ilmu Tarbiyah Dan Keguruan Uin Raden Fatah Palembang. Jurnal Tadrib, Vol. IV, No.1: 186-189.

Sugiyono. 2006. Metode Penelitian Administrasi. Edisi Revisi. Bandung: Alfa Beta.

Sugiyono. 2017. Metode Penelitian Kuantitatif, Kualitatif, dan R\&D. Bandung: CV. Alfabet.

Sukmawati, Rika. 2019. Analisis Kesiapan Mahasiswa Menjadi Calon Guru Profesional Berdasarkan Standar Kompetensi Pendidik. Jurnal Analisa, Vol.5 (1): 95-102.

Suryana. 2010. Metodologi Penelitian (Model Prakatis Penelitian Kuantitatif dan Kualitatif). Jawa Barat :Universitas Negeri Indonesia.

Undang-Undang RI No. 20 tahun 2003 Tentang Sistem Pendidikan Nasional. 2003. Jakarta: Departemen Pendidikan Nasional. 